6-3-2016

\title{
Revitalizing the Ethnosphere: Global Society, Ethnodiversity, and the Stakes of Cultural Genocide
}

Christopher Powell Ph.D.

Ryerson University

Follow this and additional works at: https://digitalcommons.usf.edu/gsp

\section{Recommended Citation}

Powell, Christopher Ph.D. (2016) "Revitalizing the Ethnosphere: Global Society, Ethnodiversity, and the Stakes of Cultural Genocide," Genocide Studies and Prevention: An International Journal: Vol. 10: Iss. 1: 44-59.

DOI:

http://dx.doi.org/10.5038/1911-9933.10.1.1364

Available at: https://digitalcommons.usf.edu/gsp/vol10/iss1/7

This is brought to you for free and open access by the Open Access Journals at Digital Commons @ University of South Florida. It has been accepted for inclusion in Genocide Studies and Prevention: An International Journal by an authorized editor of Digital Commons @ University of South Florida. For more information, please contact digitalcommons@usf.edu. 


\title{
Revitalizing the Ethnosphere: Global Society, Ethnodiversity, and the Stakes of Cultural Genocide
}

\author{
Christopher Powell \\ Ryerson University \\ Toronto, Ontario
}

\begin{abstract}
This paper uses the concepts of ethnosphere and ethnodiversity to frame the stakes of cultural genocide in the context of the emerging global society. We are in an era of rapid global ethnodiversity loss. Global ethnodiversity is important because different cultures produce different solutions to the subjective and objective problems of human society, and because cultures have an intrinsic value. Rapid ethnodiversity loss is a byproduct of the expansion of the modern world-system, and Lemkin's invention of the concept of genocide can be understood as a dialectical reaction to this tendency. The current phase of globalization creates pressures towards global monoculture, but movements towards polyculture can be observed. Genocide scholars have an interest in three underdeveloped lines of inquiry: measuring ethnodiversity loss; constructing valid measures of the vitality and life or death of cultures; and developing techniques for resolving social differences without the need for cultural consensus.
\end{abstract}

Keywords: genocide, cultural genocide, indigenous peoples, ethnodiversity, ethnosphere, world-system, difference, globalization, polyculture

\section{Introduction}

This paper uses the concepts of "ethnosphere" and "ethnodiversity" to frame the stakes of cultural genocide in the context of the emerging global society. The global ethnosphere is the totality of all living human cultures; ethnodiversity is the degree of cultural diversity in a given social arena. The high rate of language extinction in the present era suggests a correspondingly high rate of ethnodiversity loss in the global ethnosphere. I argue that global ethnodiversity is important for three reasons: first, different cultures provide different solutions to the problem of reconciling subjective motivations and the objective necessities of material production; second, different cultures produce different forms of embodied knowledge through which humans relate to nonhuman nature; and third, cultures have an intrinsic value. From this perspective, I argue that the importance of the concept of genocide derives from its role in protecting global ethnodiversity. Rapid ethnodiversity loss is a byproduct of the expansion of globalization and the incorporation of formerly autonomous cultures into networks of capitalist exploitation and state sovereignty. Raphael Lemkin's conception of genocide can be understood as a dialectical reaction to these processes; as an attempt to reconcile the universalizing claims of European Enlightenment with a particularistic valuation of local cultures. This ambitious project faces new challenges in the current era of globalization, as a truly global society takes shape for the first time in human history. Global monoculture appears to be one possible outcome of this development, but I argue it is not the only possibility; developments such as the United Nations Declaration of the Rights of Indigenous Peoples and the Bolivian Constitution of $2009^{1}$ suggest avenues towards the possibility of a global polyculture. Achieving this polyculture will require significant intellectual innovation, however. I conclude that genocide scholars have an interest in three underdeveloped lines of inquiry: measuring ethnodiversity loss; constructing valid measures of the vitality and life or death of cultures; and, most ambitiously, developing techniques for resolving social differences without the need for cultural consensus.

\section{Ethnosphere and Ethnodiversity}

The concept of an ethnosphere was coined by anthropologist Wade Davis to refer to the totality of all living human cultures on Earth at any given moment. "Culture", for social

\footnotetext{
${ }^{1}$ United Nations, Declaration on the Rights of Indigenous Peoples, Sept. 13, 2007 (UN Doc. A/RES/61/295); Plurinational State of Bolivia, "The Political Constitution of the Plurinational State of Bolivia," (Sucre: Plurinational State of Bolivia, 2009).

${ }^{2}$ Wade Davis, "The Naked Geography of Hope: Death and Life in the Ethnosphere," Whole Earth, no. 107 (2002); Wade Davis, Light at the Edge of the World: A Journey through the Realm of Vanishing Cultures (Vancouver: Douglas \& Mcintyre, 2007); see also R.J. Barendse, "The Feudal Mutation: Military and Economic Transformatios of the Ethnosphere in the Tenth to Thirteenth Centuries," Journal of World History 14, no. 4 (2003); Wayne K.D. Davies, "Globalization: A Spatial Perspective," in Unifying Geography: Common Heritage, Shared Future, John A. Matthews and David T. Herbert, eds. (London: Routledge, 2004), 200.
} 
scientists ${ }^{3}$, refers to all human accomplishments that can be taught or otherwise passed on from one generation to another. ${ }^{4}$ This includes language, beliefs, and social institutions, but also practices, knowledge, and objects made or modified by human labour. The singular "culture" refers to "a specific, historically contingent, way of life, which is expressed though its specific ensemble of artefacts, institutions, and patterns of behaviour". ${ }^{5}$ In other words, a culture is a distinct ensemble of mutually interacting symbolic and material practices that a human group uses to survive and thrive in the world. Cultures are intrinsically contested and dynamic; members differ in how they interpret and enact the culture, and they continually modify, discard, and add to the elements of the culture. Furthermore, although cultures may be said to be bounded and distinct, they interact with one another. Davis's concept of ethnosphere suggests that all the local human cultures on Earth form a global system, comparable to the biosphere, atmosphere or lithosphere, and that the dynamics and overall state of this system should concern us.

One aspect of this system is its diversity. It is difficult to directly measure the number of human cultures that exist and that have existed, but one reasonable proxy indicator is language. A language expresses not only a distinct terminology but distinctive concepts-ideas, associations, distinctions, and so on-emerging from the ways of living unique to each culture. Davis estimates that about 10,000 human languages have existed over the lifetime of our species, and that about 6,000 exist today. ${ }^{6}$ However, of these several thousand living languages, fully half are not being taught to children, which means that they are poised to become extinct when the current generation dies. Of the remainder, only three hundred are spoken by more than a million people, and only six hundred are considered stable and secure by linguists. It would appear, therefore, that the diversity of the ethnosphere is declining precipitously within our lifetime.

Some authors use the term ethnodiversity to refer to the degree of cultural diversity within a given social space. ${ }^{7}$ The construction of the term parallels that of "biodiversity", suggesting an analogy between the two. ${ }^{8}$ Biodiversity is intrinsically important because all species require other species to survive and thrive; without adequate biodiversity, an ecosystem becomes vulnerable to disruptions and to collapse. ${ }^{9}$ The decline in global biodiversity - in the diversity of the biosphereis therefore a cause for grave concern. An analogy between biosphere and ethnosphere, biodiversity and ethnodiversity, suggests that the current decline in global biodiversity could be similarly problematic.

What's more, biodiversity and ethnodiversity may be linked. Linguistic and biological diversity tend to co-occur in the same geographical spaces. Globally, approximately $70 \%$ of the world's languages are spoken in areas of high biodiversity, and even if the New Guinea Wilderness

\footnotetext{
${ }^{3}$ The changing meanings of the word "culture" itself play a part in the story of ethnodiversity loss. In eighteenth-century European thought, the term "culture" was singular and connoted "a universal scale of human progress", and "in the hands of empires wherever they imposed power it has served a useful tool for introducing elitist norms". Nigel Rapport, Social and Cultural Anthropology: The Key Concepts, 3rd ed. (New York: Routledge, 2014), 120; see also Raymond Williams, Keywords: A Vocabulary of Culture and Society (London: Fontana/Croom Helm, 1976), 76.

${ }^{4}$ D.F. Aberle et al., "The Functional Prerequisites of a Society," Ethics 60, no. 2 (1950), 102.

${ }^{5}$ Rapport, Social and Cultural Anthropology: The Key Concepts, 121; Edward Burnett Tylor, Primitive Culture: Researches into the Development of Mythology, Philosophy, Religion, Art, and Custom (New York: Gordon Press, 1974), 1.

${ }^{6}$ Gorenflo et al. give a slightly higher estimate of "more than 6,900"; see L.J. Gorenflo et al., "Co-Occurrence of Linguistic and Biological Diversity in Biodiversity Hotspots and High Biodiversity Wilderness Areas," Proceedings of the National Academy of Sciences 109, no. 21 (2012), 8035.

${ }^{7}$ Meriam A. Bravante and William N. Holden, "Going through the Motions: The Environmental Impact Assessment of Nonferrous Metals Mining Projects in the Philippines," The Pacific Review 22, no. 4 (2009), 528; Efraim Lev, "Ethno-Diversity within Current Ethno-Pharmacology as Part of Israeli Traditional Medicine - a Review," Journal of Ethnobiology and Ethnomedicine 2, no. 4 (2006); William N. Holden, "Indigenous Peoples and Non-Ferrous Metals Mining in the Philippines," The Pacific Review 18, no. 3 (2005), 433; William N. Holden and R. Daniel Jacobson, "Civil Society Opposition to Nonferrous Metals Mining in Guatemala," Voluntas 19 (2008), 333.

${ }^{8}$ Hans-Dieter Evers, Anis Yusoff, and A.BB. Shamsul, "Ethno-Diversity and Bio-Diversity: Methods and Measurement," Munich Personal RePEc Archive 24429 (2010); Hans-Dieter Evers, Anis Yusoff, and A.BB. Shamsul, "Ethnic Diversity in Malaysia-Lessons Learned from Bio-Diversity Research," in Rethinking Realities, Reimagining Pluralism: Future Landscapes of Pluralism for Democratic Societies (Bangi: National University of Malaysia, 2010).

${ }_{9}^{9}$ Bradley J. Cardinale et al., "Biodiversity Loss and Its Impact on Humanity," Nature 486 (2012), 60.
} 
Area is removed from the analysis the proportion is still $56 \%{ }^{10}$ The reasons for this are complex. In some areas, for instance, the ecological conditions producing high biodiversity have also favoured high linguistic diversity, but this is not true across the board. However, social processes are also a factor. As Gorenflo et al. point out, "the European biological expansion of people, crops, diseases, and languages served to reduce cultural and linguistic diversity in many localities on our planet."11 Many areas with high biodiversity and high ethnodiversity have been only weakly integrated into the global economy until recently. In these areas, rapid economic growth and globalization appear to be drivers of decline in both biodiversity and ethnodiversity. ${ }^{12}$

If this is true, then cultural genocide may share a common cause with anthropogenic ecocide. The term "ecocide" refers to a process of extensive damage to an ecosystem, sufficient to cause or threaten to cause a catastrophic collapse of that system. ${ }^{13}$ Anthropogenic ecocide can be carried out intentionally as part of a campaign of war or intentional genocide, but more commonly it occurs as a byproduct of economic growth. The concepts of ethnodiversity and genocide on the one hand and biodiversity and ecocide on the other, may therefore designate not only analogous but interconnected forms of systemic transformation.

\section{Ethnodiversity Loss: Causes for Concern}

I propose three and a half reasons why ethnodiversity loss should concern us. The first reason is that different cultures produce different experiences of reality. Human experiences of reality are not just mediated, but produced through social relations. ${ }^{14}$ Part of this productive process is cognitive and arises from the different conceptual schemes produced by different cultures. ${ }^{15}$ But part of this process is practical and embodied. ${ }^{16}$ For example Davis describes the Australian Aboriginal ritual of walking the Songlines:

A moment begins with nothing. A man or a woman walks, and from emptiness emerge the songs, the musical embodiment of reality, the cosmic melodies that give the world its character. The songs create vibrations that take shape. Dancing brings definition to the forms, and objects of the phenomenological realm appear: trees, rocks, streams, all of them physical evidence of the Dreaming. Should the rituals stop, the voices fall silent, all would be lost. For everything on Earth is held together by the Songlines, everything is subordinate to the Dreaming, which is constant but ever changing. Every landmark is wedded to a memory of its origins and yet always being born. Every animal and object resonates with the pulse of an ancient event, while still being dreamed into being. The world as it exists is perfect, though constantly in the process of being formed. The land is encoded with everything that has ever been, everything that ever will be, in every dimension of reality. To walk the land is to engage in a constant act of affirmation, an endless dance of creation. ${ }^{17}$

The Songlines illustrate how, in a meaningful sense, different cultures produce different realities, and the extinction of a culture is the extinction of a reality. Or, in less relativistic terms,

\footnotetext{
${ }^{10}$ Gorenflo et al., "Co-Occurrence of Linguistic and Biological Diversity," 8035; see also William J. Sutherland, "Parallel Extinction Risk and Global Distribution of Languages and Species," Nature 423 (2003).

${ }^{11}$ Gorenflo et al., "Co-Occurrence of Linguistic and Biological Diversity," 8035.

${ }^{12}$ Tatsuya Amano et al., “Global Distribution and Drivers of Language Extinction Risk," Proceedings of the Royal Society 281 (2014).

${ }^{13}$ Franz Broswimmer, Ecocide: A Short History of Mass Extinction of Species (London: Pluto Press, 2002); Polly Higgins, Damien Short, and Nigel South, "Protecting the Planet: A Proposal for a Law of Ecocide," Crime, Law, and Social Change 59, no. 3 (2013); Susana Borràs, "New Transitions from Human Rights to the Environment to the Rights of Nature," Transnational Environmental Law 5, no. 1 (2016).

${ }^{14}$ Maurice Merleau-Ponty, The Phenomenology of Perception, trans. Colin Smith (London: Routledge Classics, 2002); Alfred Schutz, The Phenomenology of the Social World, ed. John Wild, trans. George Walsh and Frederick Lehnert (Evanston: Northwestern University Press, 1967); Christopher Powell and François Dépelteau, eds., Conceptualizing Relational Sociology: Ontological and Theoretical Issues (New York: Palgrave, 2013).

${ }^{15}$ Nelson Goodman, Ways of Worldmaking (Indianapolis: Hackett Publishing Company, 1978).

${ }^{16}$ Iris Marion Young, On Female Body Experience: Throwing Like a Girl and Other Essays (Oxford: Oxford University Press, 2005).

${ }^{17}$ Davis, Light at the Edge of the World, 186.
} 
one can say that different cultures make possible different forms of human experience and, by extension, different ways of being human. Western modernity is only one modality of human experience amongst many others. There is no culture-independent method of claiming that Western modernity is the best possible of all such modalities, let alone that its merits justify the extinction of all others. Even on its own terms, Western modernity is flawed. For instance: every society faces the problem of integrating the objective necessities of material production and social interdependence with subjectively satisfying meanings. ${ }^{18}$ In modern societies, critical sociologists have observed a hollowing out of the subjectively meaningful, communicative, and emancipatory dimensions of social relations under modern conditions, a diminution of the lifeworld through a reduction of social relations to instrumental rationality.$^{19}$ These analyses suggest that, in psychological terms, intrinsic motivations are subordinated to extrinsic motivations. ${ }^{20}$ As Davis describes them, at least some Indigenous cultures appear to have done a better job of reconciling the objective necessities of material production and social interdependence with subjectively satisfying meanings ${ }^{21}$ It is precisely this reconciliation that makes so-called traditional cultural forms appear mystifying to the Western observer. But the collective spiritual wellbeing, so to speak, of even modern subjects may depend on reconnecting the objective and subjective worlds, which the modern constitution ${ }^{22}$ has sundered.

The second reason to be concerned about ethnodiversity loss has to do with material culture. Different cultures produce not only different ways of rendering the word meaningful, but different ways of acting in it materially. For example, many Indigenous peoples of the Americas cultivated forest ecosystems through sophisticated techniques that increased the supply of food substantially beyond what would have existed without human intervention, allowing the land to support an increasing population. ${ }^{23}$ European colonizers unfamiliar with these techniques, could perceive only a supposedly pristine, uncultivated wilderness, sparsely populated by people who were themselves uncultured. Cultures can enable material practices which are invisible or appear useless to members of other cultures or, more specifically, to outsiders who lack the local cultural knowledge.

In every human society, people have to interact with each other and the nonhuman world to produce the material means of their existence. ${ }^{24}$ Industrial capitalism is only one of many modes of production that humans have developed to meet this need. This mode of production has achieved wonders never before possible, both in the scale and intensity of human transformation of nonhuman nature, but this accomplishment has also seriously disturbed the ecosystems on which we rely. Capitalism is premised on constant expansion of production, but the ecosystem resources of the Earth's biosphere are not unlimited. For this reason alone, and perhaps also because of certain self-destructive tendencies built into the logic of capitalist systems, ${ }^{25}$ capitalism cannot persist indefinitely. Many Indigenous cultures, on the other hand, have devised modes of production capable of persisting over long time scales without depleting the ecosystem services on which they

${ }^{18}$ Aberle et al., "The Functional Prerequisites of a Society"; Talcott Parsons, The Social System (New York: The Free Press, 1951).

${ }^{19}$ Jürgen Habermas, The Theory of Communicative Action, Volume 2: Lifeword and System: A Critique of Functionalist Reason, trans. Thomas McCarthy (Boston: Beacon Press, 1985); Herbert Marcuse, One-Dimensional Man: Studies in the Ideology of Advanced Industrial Society, 2nd ed. (Boston: Beacon Press, 1991); George Ritzer, The Mcdonaldization of Society, 20th Anniversary ed. (Thousand Oaks: SAGE, 2012).

${ }^{20}$ Richard M. Ryan and Edward L. Deci, "Self-Determination Theory and the Facilitation of Intrinsic Motivation, Social Development, and Well-Being," American Psychologist 55, no. 1 (2000).

${ }^{21}$ Davis, Light at the Edge of the World; Wade Davis, The Wayfinders: Why Ancient Wisdom Matters in the Modern World (Toronto: House of Anansi Press, 2009).

${ }^{22}$ Bruno Latour, We Have Never Been Modern, trans. Catherine Porter (Cambridge: Harvard University Press, 1993).

${ }^{23}$ William M. Denevan, "The Pristine Myth: The Landscape of the Americas in 1492," Annals of the Association of American Geographers 82, no. 3 (1992).

${ }^{24}$ Karl Marx and Frederick Engels, "The German Ideology," in Karl Marx, Frederick Engels: Collected Works, Volume 5, Marx and Engels: 1845-47 (Moscow: Progress Publishers, 1976).

${ }^{25}$ Karl Marx, Capital: A Critique of Political Economy, Volume III, ed. Ernest Mandel, trans. David Fernbach (Toronto: Penguin Books, 1981). 
depend. The Palawa of Tasmania, for instance, flourished for ten thousand years without depleting the ecosystem of their island. ${ }^{26}$ Many of these modes of production have been dismantled through the violent expansion of the capitalist world-system. ${ }^{27}$ Some have not, however. ${ }^{28}$ And even those production modes that have been shattered have left pieces of themselves behind in the form of knowledge and practices, which could prove invaluable in the (re)construction of a sustainable relation between humans and nonhumans. ${ }^{29}$

However, this utilitarian argument for the value of ethnodiversity has sharp limits. While many threatened cultures, including many Indigenous cultures, may well have vital ecological wisdom which could benefit our collective human future, reducing the value of those cultures to that specific contribution is a mistake, for at least three major reasons. First, not all threatened cultures necessarily have such wisdom. Second, reducing the value of any culture to a single dimension stereotypes and therefore dehumanizes the members of that culture. Indigenous cultures in particular have often been reduced to the stereotype of the ecological Indian, with deleterious effects. ${ }^{30}$ Third, such a reduction can actually contribute to cultural genocide (and anthropogenic ecocide) in the form of capitalist appropriation and commodification of local ecological knowledge. ${ }^{31}$

Consequently, my third reason to be concerned about ethnodiversity loss moves from Eurocentrism into a genuinely universalistic respect for human culture. This reason is the intrinsic value of cultural difference. Each culture is an ensemble of accomplishments. As Lemkin writes:

The world represents only so much culture and intellectual vigor as are created by its component national groups ... The destruction of a nation, therefore, results in the loss of its future contributions to the world. Moreover, such destruction offends our feelings of morality and justice in much the same way as does criminal killing of a human being: the crime in the one case as in the other is murder, though on a vastly greater scale. ${ }^{32}$

In a similar vein, United Nations General Assembly Resolution 96(I) declares that genocide "results in great losses to humanity in the form of cultural and other contributions represented by these human groups". ${ }^{33}$ Hannah Arendt, in Eichmann in Jerusalem, echoes this sentiment, writing that genocide "is an attack on human diversity as such, that is, upon a characteristic of the "human status' without with the very words 'mankind' or 'humanity' would be without meaning." 34 What's more, the value of cultural difference is implied in the legal right to the self-determination of peoples, as defined in Article 1 of the International Covenant on Economic, Social and Cultural Rights $^{35}$, inasmuch as the right of a culturally defined group to self-determination logically implies a right of that group to continue to engage in the collective cultural differentiation which defines its identity.

Appreciating the value of all cultures, especially including the cultures of indigenous and tribal peoples ${ }^{36}$, requires a shift in thinking for many, because Western intellectuals have tended

\footnotetext{
${ }^{26}$ Lyndall Ryan, The Aboriginal Tasmanians, 2nd ed. (St. Leonards: Allen \& Unwin, 1996), 9.

${ }^{27}$ John H. Bodley, Victims of Progress, 6th ed. (Lanham: Rowman \& Littlefield, 2015), 9; see also Rosa Luxemburg, The Accumulation of Capital (London: Routledge, 2003).

${ }^{28}$ Erica-Irene A. Daes, Indigenous Peoples: Keepers of Our Past - Custodians of Our Future (Copenhagen: International Work Group for Indigenous Affairs, 2008); Wade Davis, K. David Harrison, and Catherine Herbert Howell, eds., Book of Peoples of the World (Washington D.C.: National Geographic Society, 2008); Joanna Eede, ed. We Are One: A Celebration of Tribal Peoples (London: Quadrille Publishing in association with Survival International, 2009); Piers Gibbon and Jane Houston, Tribe: Endangered Peoples around the World (Buffalo: Firefly Books, 2010).

${ }^{29}$ Davis, Light at the Edge of the World; Davis, The Wayfinders.

${ }^{30}$ Shepard Krech III, The Ecological Indian: Myth and History (New York: W.W. Norton and Company, 1999).

${ }^{31}$ Vandana Shiva, Biopiracy: The Plunder of Nature and Knowledge (Cambridge: South End Press, 1997).

${ }^{32}$ Raphael Lemkin, Axis Rule in Occupied Europe: Laws of Occupation, Analysis of Government, Proposals for Redress (Washington: Carnegie Endowment for International Peace Division of International Law, 1944), 91.

${ }^{33}$ United Nations, The Crime of Genocide, Dec. 11, 1946 (UN General Assembly Res. A/RES/96(I)).

${ }^{34}$ Hannah Arendt, Eichmann in Jerusalem: A Report on the Banality of Evil (New York: Viking Press, 1963), 268-69.

${ }^{35}$ United Nations, International Covenant on Economic, Social and Cultural Rights, Dec. 16, 1966 (UN Doc. A/6316 (1966)).

${ }^{36}$ Not all Indigenous peoples are tribal. Survival International defines a tribe as "a distinct people, dependent on their
} 
to value cultures according to Eurocentric terms. ${ }^{37}$ Those terms have privileged the cultural accomplishments of modern European societies and settler societies. The cultures of Indigenous peoples in Canada, for instance, have been treated as having no value, and this devaluation has helped legitimate cultural genocide. ${ }^{38}$ Non-Western cultures in general and Indigenous cultures in particular, have often been stereotyped as archaic, atavistic, fossilized; as belonging to the past, when they actually are vibrant, dynamic, and have as much a claim to the present as does Western modernity. ${ }^{39}$

Finally, the analogy between ethnodiversity and biodiversity suggests a possibility for which I have no direct evidence, but only because this evidence has never been sought. Biodiversity matters because no single species can survive on its own, that is, because of interspecies interdependence. This is the final, half reason why ethnodiversity loss should concern us. It is conceivable that cultures also require other cultures to survive. Certainly, cultures have usually, perhaps always, existed in relation to other cultures. Even before the advent of modern technologies for travel and communication there was more interaction between cultures, over longer distances, than is commonly assumed..$^{40} \mathrm{I}$ propose as a purely speculative hypothesis that monocultures in the social realm are unstable and vulnerable to collapse in the same way that are monocultures have been demonstrated to be in the biological realm. Ethnodiversity might be necessary for human survival and vitality independently of the specific contributions of particular cultures.

To sum up: (1) the ethnosphere is the totality of human culture; (2) this totality can be more differentiated or less differentiated; and (3) there are grounds for thinking that a loss of ethnodiversity is problematic for collective human wellbeing.

In light of these claims about the ethnosphere and ethnodiversity, the concept of genocide can be understood as taking on a particular significance that it does not otherwise have. Specifically, we can understand the prohibition of genocide as a means of protecting ethnodiversity. Indeed I think that, substantively speaking, this is precisely how Lemkin imagined the term when he formulated it, as the passage I quoted above indicates. ${ }^{41}$ Understanding the concept of genocide in these terms provides an elegant and compelling rationale for including both physical genocide and cultural genocide within the concept of genocide proper.

Genocide scholars are all familiar with the wide-ranging debate over the proper meaning(s) and usage(s) of the term genocide. While this debate has perhaps become tiresome, it has no easy resolution. Genocide is an inescapably contested concept. ${ }^{42}$ This means that the definitional debates surrounding the term cannot be resolved by purely rational argumentation because

land for their livelihood, largely self-sufficient, and not integrated into the national society" and estimates that there are "one hundred and fifty million tribal individuals worldwide, constituting around forty percent of indigenous individuals". "Terminology," Survival International, accessed May 15, 2016, http://www.survivalinternational.org/info/ terminology.

${ }^{37}$ Samir Amin, Eurocentrism (New York: Monthly Review Press, 1989); John M. Hobson, The Eurocentric Conception of World Politics: Western International Theory, 1760-2010 (Cambridge: Cambridge University Press, 2012); Edward Said, Orientalism (New York: Vintage Books, 1978); Ella Shohat and Robert Stam, “Chapter 1 - from Eurocentrism to Polycentrism," in Unthinking Eurocentrism: Multiculturalism and the Media (London: Routledge, 1994); Immanuel Wallerstein, European Universalism: The Rhetoric of Power (New York: New Press, 2006).

${ }^{38}$ Daniel N. Paul, We Were Not the Savages: Collision between European and Native American Civilizations, 3rd ed. (Halifax: Fernwood Publishing, 2006); Royal Commission on Aboriginal Peoples, "Report of the Royal Commission on Aboriginal Peoples," Indian and Northern Affairs Canada, accessed May 15, 2016, http://hdl.handle.net/1974/6874; Truth and Reconciliation Commission of Canada, Honouring the Truth, Reconciling for the Future: Summary of the Final Report of the Truth and Reconciliation Commission of Canada (Ottawa: Government of Canada, 2015); Isabelle Knockwood, Out of the Depths: The Experiences of Mi'kmaw Children at the Indian Residential School at Schubenacadie, Nova Scotia, 2nd ed. (Lockeport: Roseway Publishing, 2001).

${ }^{39}$ Daes, Indigenous Peoples; Davis, Harrison, and Howell, Book of Peoples; Eede, We Are One; Gibbon and Houston, Tribe: Endangered Peoples; see also S.N. Eisenstadt, "Multiple Modernities," Daedalus 129, no. 1 (2000).

${ }^{40}$ Andre Gunder Frank and Barry K. Gills, eds., The World System: Five Hundred Years or Five Thousand? (London: Routledge, 1993).

${ }^{41}$ Lemkin, Axis Rule, 91; see also Christopher Powell, “What Do Genocides Kill? A Relational Conception of Genocide," Journal of Genocide Research 9, no. 4 (2007).

${ }^{42}$ See Powell, “What Do Genocides Kill?”; W.B. Gallie, “Essentially Contested Concepts,” Proceedings of the Aristotelian Society 56 (1956). 
different definitions express different political values. As Max Weber observed, political values are ultimately subjective and beyond rationality in the strict sense of the term. ${ }^{43}$ So if, for instance, the value of the concept of genocide is primarily in the protection it affords individuals from the irrationality of collective violence, ${ }^{44}$ then it suffices to equate genocide with physical extermination, and to include cultural extermination within the concept of genocide can be viewed as counterproductive. However, we also have other concepts, including mass murder, atrocity, crimes against humanity, and human rights; all of which prohibit the negation of individual agency by collective violence. Alternatively, if the primary value of the concept of genocide is its usefulness in protecting ethnodiversity and to affirm the intrinsic value of all cultures, then it makes sense to include both physical and cultural extermination within the unqualified concept of genocide. Both interpretations are internally consistent and, in Weber's terms, value-rational. ${ }^{45}$ The latter interpretation is often implicit in the growing body of scholarship on genocides of Indigenous peoples. The culture-inclusive interpretation certainly is capable of encompassing and giving meaning to the field of genocide scholarship as a whole, including work that focuses on physical genocide. I hope that it will become common among genocide scholars in general.

\section{Genocide and Anti-Genocide in the World-System}

We can understand the concept of genocide as aimed at protecting ethnodiversity. More ambitiously, we can understand the prohibition of genocide as a systemic response to the systemic destruction of ethnodiversity.

In framing this analysis, it is important to clarify what we mean by a systemic phenomenon. Broadly, a social system is a dynamic ensemble of interconnected social actions unfolding over time. Social systems do not exist apart from, or in opposition to, human agency, but rather are immanent to agential action. ${ }^{46}$ Systems can, moreover, be comprised of multiple, competing, even mutually antagonistic institutions or movements. ${ }^{47}$ What defines a system is the interdependence of action within its network: action in any part of the system is connected to action in any other part by chains of mutual ramification. To say that ethnodiversity loss is a systemic problem is to make three key claims. First, its causes are complex and broadly distributed rather than resulting from any one single coherent intention. Second, its effects apply potentially to all members of the social system in which it occurs. Third and consequently, addressing ethnodiversity loss requires collective effort, action on many institutional fronts, and a willingness to revise very deeply embedded or taken-for-granted social practices.

For this analysis we can draw on the world-systems theory of Immanuel Wallerstein. ${ }^{48}$ Wallerstein defines a world-system as an integrated social totality that includes a single division of labour and a single dominant institution of political power. The modern world-system, which originated in Western Europe in the late 15th century, is characterized by the capitalist economy and the network of nominally sovereign nation-states (the latter of which collectively comprises a single, internally heterogeneous, social institution). Because the nation-state system is polycentric,

\footnotetext{
${ }^{43}$ Max Weber, "Science as a Vocation," in From Max Weber: Essays in Sociology, ed. H.H. Gerth and C. Wright Mills (New York: Oxford University Press, 1946); "Objectivity in Social Science and Social Science Policy," in The Methodology of the Social Sciences, eds. Edward A. Shils and Henry A. Finch (Glencoe: The Free Press, 1949); "Value-Judgments in Social Science," in Weber: Selections in Translation, ed. W.G. Runciman (Cambridge: Cambridge University Press, 1978); "Politics as a Vocation," in Weber: Selections in Translation, ed. W.G. Runciman (Cambridge: Cambridge University Press, 1978).

${ }^{44}$ Christopher Powell and Julia Peristerakis, "Genocide in Canada: A Relational View," in Colonial Genocide and Indigenous North America, eds. Andrew Woolford, Jeff Benvenuto, and Alexander Laban Hinton (Durham: Duke University Press, 2014), 71.

${ }^{45}$ See Max Weber, Economy and Society, vol. 1 (Berkeley: University of California Press, 1978), 24.

${ }^{46}$ Christopher Powell, "Radical Relationism: A Proposal," in Conceptualizing Relational Sociology: Ontological and Theoretical Issues, eds. Christopher Powell and François Dépelteau (New York: Palgrave, 2014).

${ }^{47}$ Christopher Powell, "How Epistemology Matters: Five Reflexive Critiques of Public Sociology," Critical Sociology 39, no. 1 (2012).

${ }^{48}$ Immanuel Wallerstein, The Modern World-System I: Capitalist Agriculture and the Origins of the European World-Economy in the Sixteenth Century (New York: Academic Press, 1981); Immanuel Wallerstein, Historical Capitalism (London: Verso, 1983); Immanuel Wallerstein, World-Systems Analysis: An Introduction (Durham: Duke University Press, 2012).
} 
Wallerstein categorizes the modern world-system as a world-economy, to distinguish it from the multicultural but politically monocentric world-empires like the Roman or Aztec empires, and from the autarkic local cultures or mini-systems of non-state societies. The modern world-system is the first global world-system, and its globality has had important cultural consequences.

The universalistic ideals of European Enlightenment emerged early in the expansion of the modern world-system, as an ideological expression of that expansion. ${ }^{49}$ European intellectuals observed the global expansion of their economic and political institutions and debated how best to further that expansion. The spectrum of debate regarding the fate of Indigenous peoples ran from arguing that they should be exterminated to arguing that they should be assimilated, forcibly if necessary, to Western culture - in other words, ranging from physical genocide to cultural genocide. The lopsidedness of this discourse was, of course, a function of the power imbalance between the core and periphery of the world system. European universalism, with its accompanying narratives of progress and Enlightenment, has therefore tended to be a false universalism, achieved through the universalizing imposition of one cultural pattern, a pseudo-universality achieved through the violent erasure of difference. At the same time, the rhetorical investment in ideals of universality has left openings for colonized peoples to assert themselves and demand to be included on their own terms within the cultural life of the modern world-system..$^{50}$

Eurocentric universalism is not the only ideological expression of the globalizing expansion of the modern world-system. Nationalism and racism emerged as convenient methods of organizing the relationships between ruling elites, their subjects, and colonized Others. Before the 18th century, it was not usual for rulers to claim cultural affinity with their subjects. ${ }^{51}$ The very concept of culture indicated precisely the elitist distinction between cultivated and uncultivated subjects. ${ }^{52}$ The partial democratization of state institutions, or even the threat thereof, gave tactical and strategic advantages to would-be sovereigns who claimed to share co-membership with their subjects in the nominally egalitarian and inclusive community of nationhood. ${ }^{53}$ Racism, meanwhile, helped to legitimate colonialism, slavery, segregation, and other grossly inequitable relations between persons of European and non-European descent. ${ }^{54}$ The formulation of biological conceptions of race, facilitated by the general growth in techniques for managing the biological life of populations, ${ }^{55}$ helped integrate nationalism and racism into a primordialist account of political community. Every characteristic of a population- its particular cultural accomplishments, its inherited and acquired biological attributes, and most importantly its wealth and power- could be treated as expressions of a timeless and primordial essence distinctive to that group. Social hierarchies could be treated as expressions of a natural order.

Humanist universalism and ethno-racial particularism, therefore, flourish in a dialectical relationship to each other within the modern world-system, and within universalism a second dialectic operates between Eurocentrism and a universalism inclusive of different cultures. We can understand Lemkin's project to define and abolish genocide as an attempt to synthesize the antitheses of this double dialectic. Lemkin's conceptualization of genocide in Axis Rule appears to assume a primordialist account of nationality that bears an ironic resemblance to the scientific racism of Nazi ideology. ${ }^{56}$ To a certain extent-it is important not to overstate this point-Lemkin and the Nazis shared a basic assumption, namely that nations are essential units of human social organization. One can characterize the opposition between Lemkin and the Nazis in terms of the

\footnotetext{
${ }^{49}$ Wallerstein, European Universalism.

${ }^{50}$ See e.g., United Nations, Declaration on the Rights of Indigenous Peoples; Plurinational State of Bolivia, "The Political

Constitution"; Truth and Reconciliation Commission of Canada, Truth and Reconciliation Commission of Canada: Calls to Action (Ottawa: Government of Canada, 2015).

${ }^{51}$ Michel Foucault, Society Must Be Defended: Lectures at the Collège De France, 1975-1976, ed. Arnold I. Davidson, trans. David Macey (New York: Picador, 2003), 134.

${ }^{52}$ Williams, Keywords, 77.

${ }^{53}$ Norbert Elias, The Germans, trans. Eric Dunning and Stephen Mennell (New York: Columbia University Press, 1996$), 157$.

${ }^{54}$ W.E.B. DuBois, "Prospect of a World without Race Conflict," American Journal of Sociology 49, no. 5 (1944).

${ }^{55}$ Foucault, Society Must Be Defended, 243.

${ }^{56}$ Powell, “What Do Genocides Kill?"
} 
opposite conclusions they drew from this common premise. The Nazis, of course, believed that it was necessary for the Aryan nation to dominate and destroy all other nations. Lemkin, on the other hand, believed that peaceful coexistence between nations was possible and desirable, and advocated an "appreciation of the national characteristics and qualities contributed to world culture by the different nations-characteristics and qualities which, as illustrated in the contributions made by nations weak in defense and poor in economic resources, are not to be measured in terms of national power and wealth." 57

In summation, the concept of genocide emerges as a symptom of the contradiction between universalizing and particularizing tendencies of the modern world-system. Against the grain of Eurocentric universalism which consigns non-European cultures to an inevitable death of one kind or another, the Lemkinian concept of genocide aims idealistically at a genuine universalism which includes deep cultural difference within the global human community.

\section{World Society: Ethnodiversity or Monoculture?}

As commonly used by social scientists, the term "society" connotes a distinct, bounded, functionally integrated ensemble of social institutions which together organize most aspects of the lives of the individuals within them. ${ }^{58}$ Although the modern capitalist economy has been global, or at least globalizing, from its inception, ${ }^{59}$ in other respects it has been feasible to treat the modern worldsystem as comprising a multiplicity of societies, that is - until fairly recently. Globalization theorists argue that since the 1970s, social relations which formerly took place within the boundaries of states have increasingly also taken place across state boundaries, to the extent that the image of nation-states as self-contained societies has become obsolete. ${ }^{60} \mathrm{Held}$, for example, argues that in the domains of economics, politics, military security, international law, and culture, states no longer function as containers and now appear more as nodes in a network ${ }^{61}$ Other analysts postulate the emergence of a global civil society, ${ }^{62}$ or transnational ethnic communities ${ }^{63}$ Additionally, ecological issues, such as anthropogenic climate change, can create truly global problems that may require global solutions. The upshot of these developments is that the formation of a truly global society, long foreshadowed by sociologists, ${ }^{64}$ may now be taking place.

The fate of cultural difference within this emerging global human society remains unclear. Analysts disagree over the extent to which contemporary globalization necessarily results in a homogenization of culture versus merely a global reorganization of culture. ${ }^{65}$ The tendency to dissolve the territorial boundaries between national cultures has entailed the global dissemination of Western cultural elements (the "McDonaldization" of the world), but it has also enabled the globalization of non-Western cultures as well, along with uniquely modern forms of cultural synthesis and ethnogenesis.

Despite the ambiguity of these developments, the anthropological evidence on language loss points to a very drastic reduction in ethnodiversity as a byproduct of modernization. ${ }^{66}$ Meanwhile, the persistent use of genocide both within and across nation-state boundaries ${ }^{67}$ and the mobilization

\footnotetext{
${ }^{57}$ Lemkin, Axis Rule, 91.

${ }^{58}$ Parsons, The Social System.

${ }^{59}$ Wallerstein, Historical Capitalism.

${ }^{60}$ Manfred Steger, Globalization: A Very Short Introduction, 3rd ed. (London: Oxford University Press, 2013).

${ }^{61}$ David Held, Democracy and the Global Order: From the Modern State to Cosmopolitan Governance (Stanford: Stanford University Press, 1995).

${ }^{62}$ Mary Kaldor, Global Civil Society: An Answer to War (Cambridge: Polity, 2003).

${ }^{63}$ Linda Basch, Nina Glick Schiller, and Christina Szanton Blanc, Nations Unbound: Transnational Projects, Postcolonial Predicaments and Deterritorialized Nation-States (New York: Routledge, 1994).

${ }^{64}$ Henri Saint-Simon and Augustin Thierry, "The Reorganization of European Society," in Henri Saint-Simon: Selected Writings on Science, Industry and Social Organization, ed. Keith Taylor (New York: Holmes and Meier, 1975).

${ }^{65}$ E.g. Eisenstadt, "Multiple Modernities."

${ }^{66}$ Davis, Light at the Edge of the World, 6.

${ }^{67}$ For current examples see "Countries at Risk," Genocide Watch, accessed May 15, 2016, http://genocidewatch.net/alerts-2/ new-alerts/.
} 
of cultural difference as an ideological justification for geopolitical conflict ${ }^{68}$ are consistent with a systemic tendency towards monoculture.

Elsewhere, ${ }^{69} \mathrm{I}$ have theorized this tendency in terms of the relations of dominance and submission, which have historically constituted the institution of sovereignty. My analysis builds on Elias's examination ${ }^{70}$ of the connection between state sovereignty and the subjective dispositions or habitus of individuals. Elias proposed that the humanistic culture of modern Europe results from an internalization of the power relation of sovereignty, a social constraint to self-constraint, which obliges subjects towards nonviolent forms of social interaction. I argue that a more complex and contradictory process is involved in the formation of sovereignty. What Elias calls "the civilizing process" emerges from the power struggles among autarkic feudal lords in Western Europe after the collapse of the Holy Roman Empire. When one lord is defeated militarily by another, he offers surrender and fealty in exchange for his life. This relation of deference fails to dissolve the social conditions for violence in the state that it helps establish. Rather, it defers violence, in two ways. Externally, the fealty which the knight offers his sovereign enables the sovereign to expand his own capacity for violence through the formation of larger armies, the extension of legal authority, disciplinary power, and so on. Internally, the subject absorbs the violence of the battlefield into his own self, and seeks perpetually to extract deference from others in compensation for the deference he pays the sovereign. In this way, physical contests of strength are sublimated into symbolic contests for social status, and the whole normative order of society becomes a reservoir of symbolic violence, held back by endless performances of deference. In the giving and taking of deference, both subjects identify, on unequal terms, with a shared symbolic conception of the sovereign, and when one party cannot or will not perform appropriately the performance fails and symbolic violence has the potential to become physical. Under the right conditions (interest and impunity), these performative failures can occasion genocidal violence.

This analysis suggests that the dominant political institution of the modern world-system, the sovereign state, continually reproduces the potential for genocide on an ever-expanding scale, and can accommodate deep cultural difference only uneasily. Hence Kuper's assertion that plural societies are structurally prone to genocide. ${ }^{71}$ This proneness results not from something existentially intrinsic to difference, but from the instability of the social institution which must accommodate those differences. It is the power relations and the interests at stake in the situation, not the cultural ideals of the dominant group, which determine whether genocide will take place. Thus, to take the Indigenous peoples of Canada as an example, the ability of minority groups to resist a long-term cultural genocide depends less on the ideological orientation of the ruling political party than on the power relations between those groups and the state. These relations vary complexly according to the former's access to various forms of capital, the latter's relations with its non-Indigenous subjects, Canada's fluctuating position in the world-system, and so on.

While the state system produces tendencies towards genocide, it also produces tendencies in the opposite direction. The sovereign state is not a monolith; it is an unstable and contradictory process:

social contradictions generate the conditions of their own overcoming. If the genocidal propensity of Western civilization seems to us an intolerable monstrosity, this reaction is also itself a product of the same civilization. [...] Eurocentric barbaric civilization has generated colonialism and slavery but also movements to abolish these institutions; it produces genocide but also global human rights movements and the very concept of 'genocide' as something criminal. ${ }^{72}$

\footnotetext{
${ }^{68}$ E.g. Samuel P. Huntington, The Clash of Civilizations and the Remaking of World Order (New York: Simon \& Schuster, 1996).

${ }^{69}$ Barbaric Civilization: A Critical Sociology of Genocide (Montréal: McGill-Queen's University Press, 2011).

${ }^{70}$ The Civilizing Process: The History of Manners and State Formation and Civilization, trans. Edmund Jephcott, Revised ed. (Oxford: Blackwell, 2000).

${ }^{71}$ Leo Kuper, Genocide: Its Political Use in the Twentieth Century (New Haven: Yale University Press, 1981).

${ }^{72}$ Powell, Barbaric Civilization, 301.
} 
In the flux of the contradictions of sovereignty, individuals and groups can find ways to promote projects that run directly counter to the logic of genocide.

\section{Promoting Ethnodiversity}

A political system which tolerates cultural difference only uneasily and has a chronic tendency towards assimilation and genocide does not provide a favourable environment for the longterm promotion of ethnodiversity. Nevertheless, the deferentiation which favours cultural homogenization is not the only force at work in the modern world-system. Minority cultures have found ways to resist assimilation and even to reassert themselves in many instances. The (partial) success of these reassertions is reflected in political projects which, in effect, aim towards some form of ethnodiversity. These ethnodiverse alternatives to monoculturalism have been advocated under a number of labels: multiculturalism, ${ }^{73}$ interculturalism, ${ }^{74}$ polyculturalism, ${ }^{75}$ and pluriculturalism. ${ }^{76}$ Of these, multiculturalism is probably the most well known. It is the official policy of the government of Canada, for instance. In principle, multiculturalist politics promotes acceptance of multiple cultures within a single political jurisdiction. Critics of multiculturalism, however, argue that its protection of cultural difference is superficial and shallow, extending only to private consumption activities such as foods, dances, sports, and so on. ${ }^{77}$ In Canada, for instance, official multiculturalism does not extend to recognition of Indigenous treaty rights, selfgovernance, or economic independence.

A more ambitious ideal appears in the Bolivian Constitution of 2009. This document defines Bolivia as a "plurinational" state. Article 2 spells out what this means for Indigenous peoples:

Given the pre-colonial existence of nations and rural native indigenous peoples and their ancestral control of their territories, their free determination, consisting of the right to autonomy, self-government, their culture, recognition of their institutions, and the consolidation of their territorial entities, is guaranteed within the framework of the unity of the State, in accordance with this Constitution and the law. ${ }^{78}$

The Bolivian Constitution affirms the rights of Indigenous peoples to cultural identity and practice, including rights to self-determination and territoriality, respect for traditional knowledge, collective ownership of lands and territories and of intellectual property and knowledge, a healthy environment, protection of sacred spaces, inter- and intra-cultural education, and protection for peoples in danger of extinction, along with other rights. It also promises the right "to the practice of their political, juridical and economic systems in accord with their world view."79 These rights address the material practices in which the symbolic or communicative aspects of culture are necessarily rooted.

Of course, the Bolivian Constitution owes much, in spirit and in detail, to the 2007 United Nations Declaration on the Rights of Indigenous Peoples (UNDRIP). Notwithstanding the significant compromises involved in its drafting, this Declaration specifically guarantees that "Indigenous peoples have the collective right to live in freedom, peace and security as distinct peoples and shall not be subjected to any act of genocide or any other act of violence, including forcibly removing children of the group to another group." ${ }^{80}$ It also specifically mentions the

\footnotetext{
${ }^{73}$ E.g. Will Kymlicka, Multicultural Citizenship: A Liberal Theory of Minority Rights (Oxford: Oxford University Press, 1995).

${ }^{74}$ UNESCO, "Investing in Cultural Diversity and Intercultural Dialogue," (Paris: United Nations Educational, Scientific, and Cultural Organization, 2009).

${ }^{75}$ Richard Madsen, “Global Monoculture, Multiculture, and Polyculture," Social Research 60, no. 3 (1993).

${ }^{76}$ Plurinational State of Bolivia, "The Political Constitution."

${ }^{77}$ Himani Bannerji, The Dark Side of the Nation: Essays on Multiculturalism, Nationalism, and Gender (Toronto: Canadian Scholars' Press, 2000); David Theo Goldberg, ed. Multiculturalism: A Critical Reader (Oxford: Blackwell Publishing, 1994); B. Singh Bolaria and Peter Li, Racial Oppression in Canada, 2nd ed. (Toronto: Garamond Press, 1988).

${ }^{78}$ Plurinational State of Bolivia, “The Political Constitution," Article 2.

${ }^{79}$ Ibid., Article 30.II.14.

${ }^{80}$ United Nations, Convention on the Prevention and Punishment of the Crime of Genocide, Dec. 9, 1948 (UN Doc. A/RES/3/260).
} 
importance of lands, territories, and resources as a precondition and element of Indigenous rights, including "the right to participate in decision-making in matters which would affect their rights, through representatives chosen by themselves in accordance with their own procedures, as well as to maintain and develop their own indigenous decision-making institutions" and "the right to determine and develop priorities and strategies for the development or use of their lands or territories and other resources". ${ }^{81}$

It is on these kinds of issues that the project of preventing genocides of Indigenous peoples and the larger project of promoting human ethnodiversity may face their deepest challenges. The modern world-system is organized by one single division of labour, capitalism, and one single political institution, the sovereign state. It has expanded globally to include nearly all human beings on Earth through a mix of violence and exploitation that is primitive accumulation. We can understand past and present forms of genocidal settler colonialism in terms of this ceaseless systemic tendency to make all resources available for capitalist exploitation and all persons into subjects of the state. The kinds of practical rights specified in the UNDRIP and the Bolivian gesture towards a reversal of this incorporation, that is, towards the cultivation of economic and political institutions beyond capitalism and state sovereignty.

At this point, to theorize further the kinds of social changed entailed in the struggle to end genocide requires going beyond the limits of our current knowledge. The two dimensions of the modern world-system are not merely ideological formations; they are formations of practical social relations, that is, concrete processes through which people resolve various practical problems arising from our embodied life together. To supersede either or both of these institutions requires developing alternative practices. In the political domain, it requires developing alternative means of resolving social difference- that is, means of resolving difference without the need for deference to the monolithic figure of the singular sovereign. In the terms of the foundational paradigms of modern political theory ${ }^{82}$ this is a Utopian demand, even unthinkable. But turning the unthinkable into the thinkable is precisely the work of social theory.

In conclusion, to frame the struggle against genocide in terms of promoting diversity in the ethnosphere invites genocide scholars to engage in three important lines of social-scientific research. The first is simply to define and empirically measure global ethnodiversity and ethnodiversity loss. Language loss is only one, proxy indicator of the life and death of cultures. The second is to study and theorize the coherence and resilience of cultures, the conditions under which cultures live and die. What conditions are crucial for a culture to thrive? At what point and under what stresses, does a culture dissolve irreparably, and when may a culture be said to be damaged, but not destroyed? How can a culture damaged by genocide rebuild itself, and what outside interventions can promote revitalization? Finally, the most challenging questions concern the viability of ethnodiversity in a globalized human society. As human social relations become increasingly integrated over a global scale and local autonomy becomes less and less feasible, how can substantively different cultures exist and thrive within this single global society? This involves asking how social differences can be resolved without violence and without the need for cultural homogenization.

\section{Bibliography}

Aberle, D.F., A.K. Cohen, A.K. Davis, M.J. Levy, and F.X. Sutton. "The Functional Prerequisites of a Society." Ethics 60, no. 2 (1950): 100-11. http://dx.doi.org/10.1086/290705

Amano, Tatsuya, Brody Sandel, Heidi Eager, Edouard Bulteau, Jens-Christian Svenning, Bo Dalsgaard, Carsten Rahbek, Richard G. Davies, and William J. Sutherland. "Global Distribution and Drivers of Language Extinction Risk." Proceedings of the Royal Society 281 (2014). http://dx.doi.org/10.1098/rspb.2014.1574

\footnotetext{
${ }^{81}$ United Nations, Declaration on the Rights of Indigenous Peoples, Articles 18, 32(1).

${ }^{82}$ E.g. Jean-Jacques Rousseau, "The Social Contract or, Principles of Political Right," in The Social Contract and Discourses, ed. J.H. Brumfitt, John C. Hall, and P.D. Jimack (London: J.M. Dent, 1993); Thomas Hobbes, Leviathan, or, the Matter, Forme, \& Power of a Common-Wealth Ecclesiasticall and Civill (London: Penguin, 1985); John Locke, Two Treatises of Government, ed. Peter Laslett, Cambridge Texts in the History of Political Thought (Cambridge: Cambridge University Press, 1988).
} 
Amin, Samir. Eurocentrism. New York: Monthly Review Press, 1989.

Arendt, Hannah. Eichmann in Jerusalem: A Report on the Banality of Evil. New York: Viking Press, 1963.

Bannerji, Himani. The Dark Side of the Nation: Essays on Multiculturalism, Nationalism, and Gender. Toronto: Canadian Scholars' Press, 2000.

Barendse, R.J. "The Feudal Mutation: Military and Economic Transformatios of the Ethnosphere in the Tenth to Thirteenth Centuries." Journal of World History 14, no. 4 (2003): 503-29. http://dx.doi.org/10.1353/jwh.2003.0046

Basch, Linda, Nina Glick Schiller, and Christina Szanton Blanc. Nations Unbound: Transnational Projects, Postcolonial Predicaments and Deterritorialized Nation-States. New York: Routledge, 1994.

Bodley, John H. Victims of Progress. 6th ed. Lanham: Rowman \& Littlefield, 2015.

Bolaria, B. Singh, and Peter Li. Racial Oppression in Canada. 2nd ed. Toronto: Garamond Press, 1988.

Borràs, Susana. "New Transitions from Human Rights to the Environment to the Rights of Nature." Transnational Environmental Law 5, no. 1 (2016): 113-43. http://dx.doi.org/10.1017/ $\underline{\text { S204710251500028X }}$

Bravante, Meriam A., and William N. Holden. "Going through the Motions: The Environmental Impact Assessment of Nonferrous Metals Mining Projects in the Philippines." The Pacific Review 22, no. 4 (2009): 523-47. http://dx.doi.org/10.1080/09512740903128034

Broswimmer, Franz. Ecocide: A Short History of Mass Extinction of Species. London: Pluto Press, 2002. Cardinale, Bradley J., J. Emmett Duffy, Andrew Gonzalez, David U. Hooper, Charles Perrings, Patrick Venail, Anita Narwani, et al. "Biodiversity Loss and Its Impact on Humanity." Nature 486 (2012): 59-67. http://dx.doi.org/10.1038/nature11148

Daes, Erica-Irene A. Indigenous Peoples: Keepers of Our Past - Custodians of Our Future. Copenhagen: International Work Group for Indigenous Affairs, 2008.

Davies, Wayne K.D. "Globalization: A Spatial Perspective." In Unifying Geography: Common Heritage, Shared Future, edited by John A. Matthews and David T. Herbert, 189-214. London: Routledge, 2004.

Davis, Wade. Light at the Edge of the World: A Journey through the Realm of Vanishing Cultures. Vancouver: Douglas \& Mcintyre, 2007.

- - - "The Naked Geography of Hope: Death and Life in the Ethnosphere." Whole Earth, no. 107 (2002): 57-61.

- - . The Wayfinders: Why Ancient Wisdom Matters in the Modern World. Toronto: House of Anansi Press, 2009.

Davis, Wade, K. David Harrison, and Catherine Herbert Howell, eds. Book of Peoples of the World. Washington D.C.: National Geographic Society, 2008.

Denevan, William M. "The Pristine Myth: The Landscape of the Americas in 1492." Annals of the Association of American Geographers 82, no. 3 (1992): 369-85. http://dx.doi. org/10.1111/j.1467-8306.1992.tb01965.x

DuBois, W.E.B. "Prospect of a World without Race Conflict." American Journal of Sociology 49, no. 5 (1944): 450-56. http://dx.doi.org/10.1086/219460

Eede, Joanna, ed. We Are One: A Celebration of Tribal Peoples. London: Quadrille Publishing in association with Survival International, 2009.

Eisenstadt, S.N. "Multiple Modernities." Daedalus 129, no. 1 (2000): 1-29.

Elias, Norbert. The Civilizing Process: The History of Manners and State Formation and Civilization. Translated by Edmund Jephcott. Revised ed. Oxford: Blackwell, 2000.

- - - . The Germans. Translated by Eric Dunning and Stephen Mennell. New York: Columbia University Press, 1996. 1989.

Evers, Hans-Dieter, Anis Yusoff, and A.BB. Shamsul. "Ethnic Diversity in Malaysia- Lessons Learned from Bio-Diversity Research." In Rethinking Realities, Reimagining Pluralism: Future Landscapes of Pluralism for Democratic Societies. Bangi: The National University of Malaysia, 2010.

Evers, Hans-Dieter, Anis Yusoff, and A.BB. Shamsul. "Ethno-Diversity and Bio-Diversity: Methods and Measurement." Munich Personal RePEc Archive 24429 (2010). 
Foucault, Michel. Society Must Be Defended: Lectures at the Collège De France, 1975-1976. Translated by David Macey. Edited by Arnold I. Davidson. New York: Picador, 2003.

Frank, Andre Gunder, and Barry K. Gills, eds. The World System: Five Hundred Years or Five Thousand? London: Routledge, 1993.

Gallie, W.B. "Essentially Contested Concepts." Proceedings of the Aristotelian Society 56 (1956): 167-98. http://dx.doi.org/10.1093/aristotelian/56.1.167

Genocide Watch. "Countries at Risk." Genocide Watch. Accessed May 15, 2016. http://genocidewatch. net/alerts-2/new-alerts/.

Gibbon, Piers, and Jane Houston. Tribe: Endangered Peoples around the World. Buffalo: Firefly Books, 2010.

Goldberg, David Theo, ed. Multiculturalism: A Critical Reader. Oxford: Blackwell Publishing, 1994.

Goldstein, Alyosha. "Toward a Genealogy of the U.S. Colonial Present." In Formations of United States Colonialism, edited by Alyosha Goldstein, 1-32. Durham: Duke University Press, 2014.

Goodman, Nelson. Ways of Worldmaking. Indianapolis: Hackett Publishing Company, 1978.

Gorenflo, L.J., Suzanne Romaine, Russell A. Mittermeier, and Kristen Walker-Painemilla. "CoOccurrence of Linguistic and Biological Diversity in Biodiversity Hotspots and High Biodiversity Wilderness Areas." Proceedings of the National Academy of Sciences 109, no. 21 (2012): 8032-37. http://dx.doi.org/10.1073/pnas.1117511109

Habermas, Jürgen. The Theory of Communicative Action, Volume 2: Lifeword and System: A Critique of Functionalist Reason. Translated by Thomas McCarthy. Boston: Beacon Press, 1985.

Held, David. Democracy and the Global Order: From the Modern State to Cosmopolitan Governance. Stanford: Stanford University Press, 1995.

Higgins, Polly, Damien Short, and Nigel South. "Protecting the Planet: A Proposal for a Law of Ecocide." Crime, Law, and Social Change 59, no. 3 (2013): 251-66. http://dx.doi.org/10.1007/ $\underline{\text { s10611-013-9413-6 }}$

Hobbes, Thomas. Leviathan, or, the Matter, Forme, \& Power of a Common-Wealth Ecclesiasticall and Civill. London: Penguin Books, 1985.

Hobson, John M. The Eurocentric Conception of World Politics: Western International Theory, 1760-2010. Cambridge: Cambridge University Press, 2012. http://dx.doi.org/10.1017/ CBO9781139096829

Holden, William N. "Indigenous Peoples and Non-Ferrous Metals Mining in the Philippines." The Pacific Review 18, no. 3 (2005): 417-38. http://dx.doi.org/10.1080/09512740500189199

Holden, William N., and R. Daniel Jacobson. "Civil Society Opposition to Nonferrous Metals Mining in Guatemala." Voluntas 19 (2008): 325-50. http://dx.doi.org/10.1007/s11266-0089073-9

Huntington, Samuel P. The Clash of Civilizations and the Remaking of World Order. New York: Simon \& Schuster, 1996.

Jones, Adam. Genocide: A Comprehensive Introduction. London: Routledge, 2011.

Kaldor, Mary. Global Civil Society: An Answer to War. Cambridge: Polity, 2003.

Knockwood, Isabelle. Out of the Depths: The Experiences of Mi'kmaw Children at the Indian Residential School at Schubenacadie, Nova Scotia. 2nd ed. Lockeport: Roseway Publishing, 2001.

Koonz, Claudia. The Nazi Conscience. Cambridge: Belknap Press, 2003.

Krech III, Shepard. The Ecological Indian: Myth and History. New York: W.W. Norton and Company, 1999.

Kuper, Leo. Genocide: Its Political Use in the Twentieth Century. New Haven: Yale University Press, 1981.

Kymlicka, Will. Multicultural Citizenship: A Liberal Theory of Minority Rights. Oxford: Oxford University Press, 1995.

Latour, Bruno. We Have Never Been Modern. Translated by Catherine Porter. Cambridge: Harvard University Press, 1993.

Lemkin, Raphael. Axis Rule in Occupied Europe: Laws of Occupation, Analysis of Government, Proposals for Redress. Washington: Carnegie Endowment for International Peace Division of International Law, 1944. 
Lev, Efraim. "Ethno-Diversity within Current Ethno-Pharmacology as Part of Israeli Traditional Medicine - a Review." Journal of Ethnobiology and Ethnomedicine 2, no. 4 (2006).

Locke, John. Two Treatises of Government. Cambridge Texts in the History of Political Thought. Edited by Peter Laslett Cambridge: Cambridge University Press, 1988.

Luxemburg, Rosa. The Accumulation of Capital. London: Routledge, 2003.

Madsen, Richard. "Global Monoculture, Multiculture, and Polyculture." Social Research 60, no. 3 (1993): 493-511.

Marcuse, Herbert. One-Dimensional Man: Studies in the Ideology of Advanced Industrial Society. Second ed. Boston: Beacon Press, 1991.

Marx, Karl. Capital: A Critique of Political Economy, Volume II. Translated by David Fernbach. Edited by Ernest Mandel Toronto: Penguin Books, 1978. 1885.

- - - Capital: A Critique of Political Economy, Volume III. Translated by David Fernbach. Edited by Ernest Mandel Toronto: Penguin Books, 1981. 1894.

Marx, Karl, and Frederick Engels. "The German Ideology." In Karl Marx, Frederick Engels: Collected Works, Volume 5, Marx and Engels: 1845-47. Moscow: Progress Publishers, 1976.

Merleau-Ponty, Maurice. The Phenomenology of Perception. Translated by Colin Smith. London: Routledge Classics, 2002. 1945.

Parsons, Talcott. The Social System. New York: The Free Press, 1951.

Paul, Daniel N. We Were Not the Savages: Collision between European and Native American Civilizations. 3rd ed. Halifax: Fernwood Publishing, 2006.

Plurinational State of Bolivia. "The Political Constitution of the Plurinational State of Bolivia." Sucre: Plurinational State of Bolivia, 2009.

Powell, Christopher. Barbaric Civilization: A Critical Sociology of Genocide. Montréal: McGill-Queen's University Press, 2011.

- - -. "How Epistemology Matters: Five Reflexive Critiques of Public Sociology." Critical Sociology (2012).

- - -. "Radical Relationism: A Proposal." In Conceptualizing Relational Sociology: Ontological and Theoretical Issues, edited by Christopher Powell and François Dépelteau, 187-208. New York: Palgrave, 2014.

- - - "What Do Genocides Kill? A Relational Conception of Genocide." Journal of Genocide Research 9, no. 4 (2007): 527-47. http://dx.doi.org/10.1080/14623520701643285

Powell, Christopher, and François Dépelteau, eds. Conceptualizing Relational Sociology: Ontological and Theoretical Issues. New York: Palgrave, 2013. http://dx.doi.org/10.1057/9781137342652

Powell, Christopher, and Julia Peristerakis. "Genocide in Canada: A Relational View." In Colonial Genocide and Indigenous North America, edited by Andrew Woolford, Jeff Benvenuto and Alexander Laban Hinton. Durham: Duke University Press, 2014. http://dx.doi.org/10.1215/9780822376149-004

Rapport, Nigel. Social and Cultural Anthropology: The Key Concepts. 3rd ed. New York: Routledge, 2014.

Ritzer, George. The Mcdonaldization of Society. 20th Anniversary ed. Thousand Oaks: SAGE, 2012.

Rousseau, Jean-Jacques. "The Social Contract or, Principles of Political Right." Translated by G. D.H. Cole. In The Social Contract and Discourses, edited by J.H. Brumfitt, John C. Hall and P.D. Jimack, 179-309. London: J.M. Dent, 1993.

Royal Commission on Aboriginal Peoples. "Report of the Royal Commission on Aboriginal Peoples." Indian and Northern Affairs Canada. Accessed May 15, 2016, http://hdl.handle. net/1974/6874.

Ryan, Lyndall. The Aboriginal Tasmanians. 2nd ed. St. Leonards: Allen \& Unwin, 1996.

Ryan, Richard M., and Edward L. Deci. "Self-Determination Theory and the Facilitation of Intrinsic Motivation, Social Development, and Well-Being." American Psychologist 55, no. 1 (2000): 68-78. http://dx.doi.org/10.1037/0003-066X.55.1.68

Said, Edward. Orientalism. New York: Vintage Books, 1978.

Saint-Simon, Henri and Augustin Thierry. "The Reorganization of European Society." In Henri Saint-Simon: Selected Writings on Science, Industry and Social Organization, edited by Keith Taylor, 130-36. New York: Holmes and Meier Publishers, 1975. 
Schutz, Alfred. The Phenomenology of the Social World. Translated by George Walsh and Frederick Lehnert. Studies in Phenomenology and Existential Philosophy. Edited by John Wild. Evanston: Northwestern University Press, 1967.

Shiva, Vandana. Biopiracy: The Plunder of Nature and Knowledge. Cambridge: South End Press, 1997.

Shohat, Ella, and Robert Stam. "Chapter 1 - from Eurocentrism to Polycentrism." In Unthinking Eurocentrism: Multiculturalism and the Media, 13-49. London: Routledge, 1994.

Steger, Manfred. Globalization: A Very Short Introduction. 3rd ed. London: Oxford University Press, 2013. http://dx.doi.org/10.1093/actrade/9780199662661.001.0001

Sutherland, William J. "Parallel Extinction Risk and Global Distribution of Languages and Species." Nature 423 (2003): 276-79. http://dx.doi.org/10.1038/nature01607

Truth and Reconciliation Commission of Canada. Honouring the Truth, Reconciling for the Future: Summary of the Final Report of the Truth and Reconciliation Commission of Canada. Ottawa: Government of Canada, 2015.

- - - Truth and Reconciliation Commission of Canada: Calls to Action. Ottawa: Government of Canada, 2015.

Tylor, Edward Burnett. Primitive Culture: Researches into the Development of Mythology, Philosophy, Religion, Art, and Custom. New York: Gordon Press, 1974. 1871.

UNESCO. Investing in Cultural Diversity and Intercultural Dialogue." Paris: United Nations Educational, Scientific, and Cultural Organization, 2009.

United Nations. Convention on the Prevention and Punishment of the Crime of Genocide, Dec. 9, 1948. UN Doc. A/RES/3/260.

- - - Declaration on the Rights of Indigenous Peoples, Sept. 13, 2007. UN Doc. A/RES/61/295.

- - - International Covenant on Economic, Social and Cultural Rights, Dec. 16, 1966. UN Doc. A/6316 (1966).

- - - . The Crime of Genocide, Dec. 11, 1946. UN General Assembly Res. A/RES/96(I).

Wallerstein, Immanuel. European Universalism: The Rhetoric of Power. New York: New Press, 2006.

--- . Historical Capitalism. London: Verso, 1983.

- - - . The Modern World-System I: Capitalist Agriculture and the Origins of the European WorldEconomy in the Sixteenth Century. New York: Academic Press, 1981.

- - - . World-Systems Analysis: An Introduction. Durham: Duke University Press, 2012.

Weber, Max. Economy and Society. Vol. 1, Berkeley: University of California Press, 1978.

- - - " "Objectivity in Social Science and Social Science Policy." In The Methodology of the Social Sciences, edited by Edward A. Shils and Henry A. Finch, 50-112. Glencoe: The Free Press, 1949.

- - -. "Politics as a Vocation." Translated by Eric Matthews. In Weber: Selections in Translation, edited by W.G. Runciman. Cambridge: Cambridge University Press, 1978.

- - - . "Science as a Vocation." In From Max Weber: Essays in Sociology, edited by H.H. Gerth and C. Wright Mills, 129-56. New York: Oxford University Press, 1946.

- - - "Value-Judgments in Social Science." Translated by Eric Matthews. In Weber: Selections in Translation, edited by W.G. Runciman, 69-98. Cambridge: Cambridge University Press, 1978.

Williams, Raymond. Keywords: A Vocabulary of Culture and Society. London: Fontana/Croom Helm, 1976.

Young, Iris Marion. On Female Body Experience: Throwing Like a Girl and Other Essays. Oxford: Oxford University Press, 2005. http://dx.doi.org/10.1093/0195161920.001.0001 